\title{
GELENEKSEL TIBBİ BİR UYGULAMA OLARAK ÇÖPÇÜLÜK
}

\author{
Prof. Dr. Fuzuli BAYAT*
}

Öz: Geleneksel tıbbın (türkeçareliğin) en geniş bilinen sahalarından biri de çöpçülüktür. "Çöpçü” boğazda ilişip kalan çekirdek, et parçası, kemik ve diğer gıda kalıntılarını geleneksel yolla, çoğu zaman üflemekle çıkaran tabiplere verilen isimdir. Eğer sınıkçılık, ebecilik (mamaçalık), hacamatçılık artık çağdaş tıbbın daha çok gelişmekte olan alternatif sahalarının etkisiyle yavaş-yavaş unutulmaya, tarihe karışmaya yüz tutmuşsa, çöpçülük hâlen kendi etki gücünü korumakta, hatta son 20-25 yılda daha çok artım göstermektedir. Modern tıbbın da aciz kaldığı boğazda gıda kalıntısının kalmasını halk arasındaki çöpçü denilen insanlar, esasen de kadınlar tedavi ederler. Özellikle 3-8 yaş arası çocukların boğazlarında çöp kalması olayı çağdaş tıbba göre imkânsızdır. Ancak şunu doktorların kendileri de tastik etmeğe mecburdurlar ki yemekten-içmekten kesilen, ısıtması düşmeyen çocuğu yalnız çöpçü tedavi etmektedir. $\mathrm{O}$ hâlde çöp dediğimiz rahatsızlığı şöyle tanımlamak mümkündür: Yemek zamanı gıdanın nefes ve gıda borusunun arasındaki küçük deliğe düşen kısmına çöp denilir. Genelde büyükler bu problemi kolaylıkla - öksürmekle aradan kaldırırlar. Ancak bebekler, kü̧̈ük yaşlı çocuklar bunu yapamazlar.

Çöpçülük vergili adamların mesleğidir. Çöpçülerin söylediklerine bakı1ırsa bu sanatı öğrenmek imkânsızdır, o insana vergi olarak verilir. Diğer taraftan çöpçülüğün soyla geçtiği de bilinmektedir. Bu cihetleriyle çöpçülük şamanlıkla aynı anlam düzeyinde yer alır.

Bildiride çöpçülerin gida borusunda ilişip kalan çöpü çıkartmak için iki metoddan yararlanmaları da kaydedilmiştir:

1. Üfürme yoluyla. Çocukların burnuna üfürmekle onu öğüdür ve çöpü boğazdan dışarı salıverirler. 2. Ötürme yoluyla. Çocuğun gıda borusuna barmakla hafifçe basmakla çöpü mideye ötürürler.

Anahtar Kelimeler: Çöpçülük, geleneksel tıbb, vergi, üfürme, ötürme

\section{CHOPCHULUK(QUACK DOCTORING) AS A TRADITIONAL APPLICATION METHOD}

Absrtact: One of the professions spread very much in quack doctoring is "chopchuluk". "Chopchu" (a quack doctor) is a name giving to a quack doctor who cleans the throat from the seeds, meat pieces, bones and other food remainders with traditional ways, including blowing. If the profession of a bone-setter, midwifery and

Geliș tarihi: 11.12.2017

Kabul tarihi: 12. 12. 2017

*. Millı̂ Bilimler Akademisi/Bakü. (Yazı, Azerbaycanlı bir öğretim üyesine aittir. Dil ve anlatıma dokunulmamıştır. 
others have been begun to be forgotten, to mix to the history with the attitude of the alternative branches of the modern medicine, but the "chopchuluk" has protected its influence power, even during 20-25 years it has been increased. So "chopchuluk" is treated only by the quack doctors, especially by women. Especially the event of having food remainders in 3-8 years of children's throat is impossible due to the modern medicine. But the doctors are compelled to affirm that the child having the high temperature and not having the meal for many days can be only treated by quack doctors. The part between the windpipe and gullet is called "chop" and the food falls usually to that place during the eating process. In general the olds solve this problem easily with the help of cough. But the kids, the little children can't do it.

"Chopchuluk" is a profession of a talented people. According to their thought to learn this profession is impossible, it must be given a person as a gift. On the other hand it is said that this ability is given by the family. Due to these characters "chopchuluk" takes place in the same semantic circle.

In the report it is also mentioned that in order to clean the windpipe and the gullet two methods are used.

1. Whith blowing

2. By the passing

Key Words: Chopchuluk, the traditional medicine, gift, blowing, passing

\section{Giriş}

Türk milletinin geleneksel tıbbi uygulama biçimine türkeçarelik denilir. ${ }^{1}$ Türkeçarelik, halk hekimliğini, büyüsel, magik uygulamaları da içine alan ve Türklere özgü tedavi sistemidir. Geleneksel tıbbi yolla tedavi edenlere de türkeçare denilir. Ara hekimliği, loğmanlık adlarıyla da bilinen türkeçarelik/türkeçare, halk tebabetinin hastalıkları tedavi, iyileştirme yollarından biri olup bin yıllar boyu biriken bütün geleneksel tedavi usullerinin toplamıdır. Aslında türkeçare denilen halk hekimliği daha fazla bitkilerle, otlarla tedavi yapmak anlamında kullanılır. Hiçbir kimyevi katkısı olmadan, değişik bitkilerden, çiçeklerden, meyvelerden, ağaç kabuklarından, ot köklerinden vs. hazırlanan, laboratuvarda denenmeden yapılan bu tür ilaçlarla mualiceye türkeçarelik denilir. Halk arasında türkeçareliğin bin bir derde ilaç olduğuna inanılır. Türkeçarelik, fiziksel hastalıkları, ruhi bozuklukları, sonsuzluğu, çocuk doğurmayı da içine alan bir çok sahalara bölünmüştür. Şöyle ki kırık, çıkık ve kemik çatlarını tedavi eden sınıkçı veya kırıkçılar, bitki ve meyvelerle, otlarla çeşitli hastalıkları tedavi eden otaçılar, bitki, meyve vs. hazırlanan melhemlerle, çaylarla, gıdalarla sağaltma yapan lokmanlar, kan alma, banka salmayla sağaltma yoluna baş

1. Türkeçare terimi Türklere özgü çare, ilaç şekli olup tedavi, iyileştirme yöntemi anlamına gelir. Bu terim daha çok Azerbaycan'da kullanılmaktadır. 
vuran hacamatçılar, çocuk doğumu yaptıran, sonsuzluğu tedavi eden ebe/hebe/mamaçalar gibi halk hekimleri vardır. Türkeçarelikte en geniş yayılan halk hekimliğinden biri de çöpçülüktür. Eger sınıkçılık, hebeçilik (mamaçalık), otaçılık, hacamatçılık muasır tıbbın gelişmesiyle yavaş-yavaş unutulmağa, tarihe karışmağa yüz tutmuşsa, çöpçülük halen de kendi etki alanını ve eski gücünü korumakta, hatta son 20-25 yılda daha da artış göstermektedir. Nitekim muasır tıbbın da tedavide aciz kaldığı boğazda her hangi bir nesnenin kalma olayını, toplumda esasen kadınlardan ibaret olan ve çöpçü denilen hekimler sağaltırlar. Özellikle 3-8 yaş arası çocukların boğazlarında çöp kalması olayı modern tıbba göre, imkansızdır. Ancak şu gerçeği tıbb doktorları da tasdik etmeğe mecbur kalırlar ki yemekten-içmekten kesilen, harareti düşmeyen çocuğu yalnız çöpçü tedavi edebilir.

Bunu elde olan veriler de tasdik edir. Nitekim lor doktorunun tespitleri bu yöndedir: "Tıbda onun mualice kaidesi var, sadece her hekim onu bilmez. Onu da yă̆ vasitesiyle edirler. 3 yaşına kadar çocuklarda alt çene kafada yegane hareket eden kemiktir. Küçük yaşlı çocuklarda alt çene kemiği hâlen de yeterince berkimediği ve onu harekete getiren lifler (Muscle) zayıf olduğu için çöp kalır. Çöpçüler de bilmeden alt çene lifini zedeleyirler. Sonradan çocukların alt çene kemiği ve onun etrafındaki lifler zedelenir. Daha sonra düzgün oturmayan alt çene probemleri başlar. Başka problemler de yaranır: Alt ve üst çene dişleri düzgün oturmur, üst-üste logopedik problemler yaranır ve çocuklar sert gıdanı çeğnemeği sevmirler. Bugünün belalarından biri de çocuklardan çoğunun parça et yememesidir. Sonra nefes alma problemleri de belirir. Farangit, tonzilit ortaya çıkır. Eğer çocuklarda bir defa çöp kalıpsa onu çıkartmak olar. Bu iş ikinci defa tekraralanırsa o hâlde boğazda problem var demektir, onu tedavi etmek lazımdır. Bunun defalarla şahidi olmuşam ki bebekken çöpçüye sık sık baş vuranlar 6-8 yaşarası boğaz-burun problemleriyle ve alt çene limfa problemleriyle karşılaşırlar" (news.day.az/society/284793. html).

“Çöpçü” adlandırılan halk hekimleri boğazda ilişip kalan çeşitli meyve çeğirdeklerini, kemik ve gıda kalıntılarını çıkarmakla ün kazanmış insanlardır (Алекперли 2001: 31).

Azerbaycana özgü olan çöpçülük olayı toplum arasında en çok tartışma konusu olan ve modern tıbbın da en çok üzerine gittiği türkeçarelikten biridir. 


\section{Çöpçülük ve Muasır Tıbb}

Bugün güçlenmekte olan tebabet alternatif tıbbın, özellikle de geleneksel halk hekimliğinin bir çok metotlarına baş vursa da çöpçülüğü, sınıkçılığı, üflemekle, dua, nusha yazmakla ruhi hastaları sağaltmağa çalışanları, cin çıkaranları kabul etmez. Ateist bir rejimde yaşamış, dine, ruhani aleme inanmayan, en iyi durumda dini değerlere lakeyt kalan bir toplumda duahanların, üfürükçülerin, cinçilerin yok edildiği bir zamanda çöpçülüğün artış göstermesi paradoksal bir durum sergilemektedir. Azerbaycan'da bağımsızlıktan sonra Milli az., Qadınlar.biz saytlarında çöpçüleri ifşa etmek için yazılan çok sayıda yazılar da durumun fazla değişmediğinden haber verir. $\mathrm{Bu}$ ve buna benzer saytlarda çöpçülere karşı muasır tıbb tarafından savaş açıldığ 1 artık bir gerçektir. Mesela Milli az. saytında lor doktorlarıyla ve çöpçüye bş vuranlarla yapılan çok sayıda röportaj da verilmiştir. Bu musahibelerde şahidler çocuklarını veya torunlarını çöpçüye götürdüklerini, onlara inandıklarını belirtirler. Çöpçülere inanmayanlar ve onların yardımına baş vurmağı tehlikeli hesap edenler ise genelde doktorlardır. Milli az. saytında verilen bir röportajda "İlmi-araştırmalar ve Pediyatri Enstitüsünün müdiri Nesib Quliyev kesin şekilde çöpçüye baş vurmağın aleyhine olduğunu bildirir: "Önermirem. Dünyada çöpçü adlı görev yoktur. Azerbaycan'dan başka hiçbir ülkede çöpçülük yapmazlar. Bu o anlama gelir ki orada çocukların hepsinde çöp kalıp?" Poliklinikte çalışan Dilefruz doktor da ebeveynleri çöpçüye inanmamağa çağırır: "Çöpçüye inanmıram. Çocuğun uzun zaman hararetinin olmasına ve kusmasına geldikte ise bu, yeni bir virus olabilir. Şimdi çocuklar arasında yeni bir virus yayılıp ki çocuklar hastalandıkta uzun zaman 1sıtmaları düşmür, iştahsızlık ve süslük müşahede edilir. Bu zaman çöpçüye değil, doktora baş vurmak lazımdır". Özel bir klinikte çalışan doktor Vidadi Cebiyev ise bildirir ki son yıllar çocuklarda burun- boğaz problemleri keskin şekilde artış gösterir: "Bunu çöple bağlamak doğru değildir. Türkeçarelere baş vurmak hastalığın artmasına sebep olabilir".

Geleneksel tıbbın çocuk hastalı̆̆ı, özellikle de burun-boğaz hastalığı konusunda en iyi bilicisi hiç kuşkusuz çöpçülerdir. Muasır tıbbın çöpçülere karşı savaş açmasına bakmaksızın çöpçülük geleneksel türkaçerelik mesleği gibi genelde toplumun çoğunluğu tarafından inanılan halk hekimleridir. Modern tıbb boğazda veya burunda her hangi bir nesnenin kalmasını tasdik etse de bunun tedavi yollarını doktorlara 
bırakır. Nitekim resmi tıbbın mevkiyine göre, V.Zeynalova və S. Mustafayeva'nın da yazdıkları gibi eğer lor doktorunun tedavisi bir sonuç vermezse o hâlde boğazda ilişip kalan yabancı nesnenin çıkarılması için farinkoskopi veya ezofakoskopi talep edilir. Yabancı nesnelerin keyfi şekilde çıkarılması gelecekte zararlı sonuçlar doğurabilir. Tasavvur edin ki çocuğun burnunda bir şey kalıp. Burunun akması yüzünden yabanc1 nesne bulunmayabilir, aynı zamanda, ikinci burun deliyi, nefesalma işlevini yerine getirir, çöpçü ise üfürmekle burundaki nesneni nefes yoluna sokabilir. Çöpçüye gitmek bazı kötü sonuçlar da doğurabilir. Bununla beraber binlerle insan, özellikle de analar iddia edirler ki çocuğa antibiyotik veren muhafezekar doktordan çöpçü yeterince etkili tedavi yapabilir. Ancak gıda kalıklarının boğazdan çıkarılmasının uzmanı olarak bilinen çöpçü, yalnız bizim Azerbaycan'da vardır. Bu fikre itiraz edenler şöyle derler ki başka ülkelerde de çocukların kırtlağında yabancı nesne kalır ve onu çıkarırlar. Ancak diğer ülkelerde bununla ara hekimleri değil, tıbb fakültelerinde özel eğitim görmüş profesyonel doktorlar ilgilenirler. Diğer taraftan çöpçüler de başka geleneksel meslek uzmanları gibi aslında iyi psikologdurlar ve çok vakit heyecanlanmış analar çocuğun kırtlağından neyinse çıktığını görüp derhal rahatlayırlar (Zeynalova 2013).

Son dönemlerde muasır tıbbın gelişmesine bakmaksızın Azerbaycan'da hem maddi sıkıntı yüzünden hem de en esası inanç nedeniyle çöpçülere baş vurma halleri artış gösterir. Bunu tıbb profesörü Adil Qeybulla da kaydedir ki çöpçüye muracaat edenlerin sayının artması ciddi bir problemdir: "Çok insan çöpçü adı altında dolandırıcılık yapır. Çöpçüye götürülen çocuklar, çeşitli enfeksiyonlar kapabilirler. Çöpçü, genelde elini yıkayır ve boğaza salır, ancak sterilizasyon meselesi gözlenilmir. Çocuklar ise enfeksiyona hassas olurlar, çok kolaylıkla enfeksiyon gırtlak, udlak arkası bölgeye geçe ve çocuk için problem yaradabiler. Bazen çocuklarda değişik iltihabi haller olur, böyle durumlarda, çöpçünün müdahelesi o bölgede enfeksiyonun yayılmas1na getirip çıkarabilir. Buna göre çöpçüye yok, burun-boğaz doktoruna baş vurmak lazımdır" (news.day.az/society/284793.html).

Çocuk doktoru Arzu İsayeva ise bildirir ki çöpçüde olan her hangi bir hastalık çocuğa da geçebiler. Onun fikrince değişik enfeksiyon hastalıklar çöpçüden çocuğa geçebilir. Çünkü çöpçü, çocuğun burnundan üfürür, nefesi, ağız suyu çocuğun vücuduna düşür" (news. day.az/society/284793.html). 
Aparılan araşdırmalar da çöpçülere birmanalı münasebetin olmadığını gösterdi. Tabii ki çöpçüye inanmayanlar ilk sırada doktorlardır. İkinci yerde genelde kendini okumuş, şehirli gösteren, inamı ve inancı zayıf veya hiç olmayan insanlardır. Üçüncü yerde yalancı çöpçüye rast gelmekle bu türkeçarelere inamını kaybedenlerdir. Buna bakmayarak ister üniversite okumuş, eğitimli ister lise mezunu ister köy isterse de şehirli olsun, çöpçüye inananların sayı çokluk oluşturur. Mesela, Milli.az saytının geçirdiği sorguda çöpçüye inananların düşünceleriyle tanış olmak mümkündür. Aşağıda onlardan yalnız bir örnek vermekle kifayetleneceğiz. Burada insanların çöpçülere ve çüpçülük mesleğine bakışları, sosyal-ekonomik durumları, bazı polikliniklerin ve polislerin onlara münasebeti bakımından Milli.az saytında bir bayanın, çocuğunu tedavi etmiş bir çöpçüyle röportajını vermeği uygun bulduk:

"Bu röportaj kimde ise istehza doğurabilir, kimse düşüner ki reklam karakterli yazıdır. Asla. Sadece bir gün üç yaşlı kızım 39 derece hararetle gece sabaha kadar ağzına aldığı bir yudum suyu dahi yudamayıp kaytardı. Sabah açılan gibi, çocuğu alıp hastaneye gittim. Net bir teşhis koyamadılar, gah dediler zehirlenip, gah dediler soyuklayıp, sonda hiçbiri de kendini doğrultmadı.

Dörd gün çocuğun mide-bağırsaklarını yuyup, iyneden, ilaçtan, serumdan yeritdiler vücuduna. Sonunda çocuk süst durumda, gözleri yumulu kaldı. Gördüm artık seslenmelerime tepki vermiyor, cümaertesi gecesi hastaneden zorla da olsa, çocuğu alıp eve getirdim. Beklenmedik hâlde bir çalışma arkadaşım telefon açıp maslahat gördü ki onu çöpçüye gösterek. Eve çöpçü getirdik. Çöpçü çabukça işini yapıp gidenden hemen sonra, hiçbir tepki göstermeyen çocuk, yerinden kalktı, oturdu, yemek istedi. Yeyip, üstünden de meyve şiresi içdi, rahatça uyuyup yatt1.

İkinci defa ise harareti yükselen gibi doktora değil, çöpçüye götürdüm. Eve döndükde hiçbir harareti kalmamıştı, yediklerini de geri kaytarmırdı" (news.day.az/society/284793.html).

Buna rağmen ebeveynlerden çöpçülere inanmayanlar, onları yalancı adlandıranlar da vardır. Bu konuyla bağlı R.Eyvazkızı şöyle yazır: "Çağdaş dünyada az insan vardır ki çocuğunu çöpçüye götürmesin. Bazıları hatta bunu verdiş haline çevirip. Çocuk yemekten kesildi, harareti kalktı, karın ağrıları başladı hemen doktora değil, çöpçüye baş vururlar. Hatta bunu her hafta tekrarlayanları da biliyorum. Onlar şöyle 
derler ki çöpçü olmasaydı çocuk ölerdi...” Daha sonra araştırmacı kendi başına gelenleri bildirerek çöpçüleri para koparmak için her türlü dolanbazlıktan yararlandığını bildirir (Eyvazkızı 2012).

Her hâlde Azerbaycan'a özgü olan çöpçülük fenomenolojisi diğer Türk topluluklarında rastlanmasa da buna benzer veya yakın bazı uygulamalar mevcuttur. Mesela, Türkiye'nin Karadeniz bölgesinde çocuklarda boğaz boşluğunda yiyecek kalıntılarının kalması olayı olmasa da büyüklerde, genellikle yaşlı erkeklerde görülen kuplika düşmesi olayı vardır. $\mathrm{Bu}$, boğazın iç kısmında bulunan ve dışardan görülen tomurcuğun yöresel adı ile kuplikanın düşmesi sonucu yaranır. Bu durumda ses kısıklığı, yutma zorluğu oluşur. Kuplikanın tedavisi şu şekildedir; kaşığın sapına tuz koyulur. Tuzlu tarafı ağızda olacak şekilde kaşık dişlenir ya da dilin altına yerleştirilir. Dağa doğru dönülüp 3 defa "Dalınla budağınla yutayım seni," denir (S.Sinoğlu). Özbeklerde de çöpçülük mesleği ve çöpçü denilen halk hekimi yoktur, ancak geleneksel yollarla burun, boğaz ve kulak hastalıklarını tedavi eden çilleçi denilen türkeçare var. Özbek araştırmacı D. Hamroyeva' nın söylediklerine göre çilleçi genelde boğaz ağrısını burun ve kulakla bir yerde sağaltmağa çalışır. Çilleçi küçük çocukların burun ve kulaklarına soktukları ve çıkarılması zor olan şeyleri özel bir metodla çıkarır.

\section{Çöpçülerin Tedavi Yöntemleri}

Geleneksel halk tebabetinin geniş yayılan sahalarından biri de çöpçülükdür. "Çöpçü" adlandırılan halk tabipleri boğazda ilişip kalan çeğirdek, kemik, et parçası ve diğer gıda kalıklarını çıkarmakla ün kazanmış insanlardır (Alekberli 2005: 168).

Çöp, türkeçare hekimlerin dediklerine göre nefes ve gıda borusunun arasındaki küçük boşlukta ilişip kalan yiyecek kalıntılarına elma, apelsin, mandarin kabuğuna veya çeğirdeğine, et parçası, sakız, şeker kağitlarına, oyuncak ve boncuklara vs. verilen addır. Genelde büyükler bu problemi kolaylıkla - öksürmekle giderebilmektedirler. Ancak bebekler, küçük yaşlı çocuklar bunu yapamazlar. Her firsatta eline geçeni ağzına aparan çocukların boğazında çöp kalma olayları sık sık baş verir. Bazı çocuklar yeyecekleri gıdalara dikkatle baktıklarından onlarda çöp kalma olayı görülmez (http://qadinlar.biz). O nedenle bazı ebeveynler çöpçüye inandıkları hâlde, bazıları bunu kabul etmez. Muşahede, mükaleme, gözlem ve derleme sonucunda boğazda ilişip kalan çeğirdek, et parçası, kemik ve diğer gıda kalıntılarını gele- 
neksel yolla çıaran çöpçü denilen halk hekimleri, esasen iki metoddan yararlanırlar:

1. Üfürmekle. Bu hâlde çöpçü, boğazda ilişis kalan yabancı nesneni yerinden tepretmek ve çıkartmak için çocuğun burnundan üfürür, çocuk öğüyür ve boğazda kalan çöp yere veya çöpçünün eline düşür.

2. Ötürme yoluyla. Çöpçü, çocuğun gida borusuna barmakla hafifçe basmakla çöpü mideye ötürür.

Aslında söyleşi yaptığımız çöpçülerin kendileri de bu iki metottan bahis etdiler ve en etkili olanının çöpü, üfürme yoluyla dışarı çıkartma olduğunu bildirdiler. "Çöpü ötürmek iyi hal değil. Çöp büyükde de kalanda çıkartıram. Büyükler de gelir, balığ kemiği kalır boğazlarında çıkartıram. Çoğunu yapmıram. Çöpü çöle çıkarıram. İçeri ötürsem mideye-zada batar" (Gülcahan (Reyhan) Elekberova). Ancak çöpü mideye ötüren türkeçareler de var. Nitekim Azerbaycan'ın KuzeyBatı bölgesinde yerleşen Kazak ilçesinde alan araştırması yaparken kendini hanıkçı (henekçi) adlandıran halk hekimi, boğazı sığamakla çöpü mideye ötürdü. Bunun zererli olup-olmadığını sordukta, zararı yoktur, yemekle beraber dışarı atılır, cevabını verdi.

Çöpü içeri ötürenlerin üfürmekle çıkaranlara göre az olduğunu ve fazla rağbet görmediğini de kaydetmek lazımdır. "Menim kendi halam çöpçü olup. Ama, dışarı çıkarmağnan yok, pülemeğnen ötürüp çöpü içeri” (Tahir Hüseynov).

Her bir çocukta çöp kalma emareleri aynı olur. Bunlar:

1. Geceler, çocuğun uykudayken yatağında sık sık çevrilmesi, rahatsız olması, kötü uyuması

2. Uyurken arka kısmını kaldırması ve başını yastığa sürtmesi

3. Gün boyu her defakından farklı olarak daha çok su içmesi

4. Kipriklerinin nemli olmas 1

5. Kipriklerinin dane-dane olmas1, dik durumda olmas1 derhal sonra)

6. Öğüyüp gıdanı kaytarması (özellikle uyurken, yemekten

7. Hararetinin en az 38 olmas1

8. Yemekten (en sevdiği yemekten de) imtina etmesi veya diğer günlere nazaran daha az yemesi

Eğer çocukta son üç hal varsa, o zaman çöp artık üç gündür ki boğazda kalmıştır, anlamına geir. Böyle oldukta çocuğu mutlaka çöpçüye göstermek lazımdır (http://qadinlar.biz). 
Deneyimli çöpçülerin söylediklerine göre, "eğer çocukta yukarıda sıralanan ilk 5 elamet varsa, diğer 3 elametin kendini göstermesini beklemeden çöpçüye gitmek gerekir. Çöpçüler çöpü çıkarttıktan sonra ne yapılmasını da tavsiye edirler:

"Çünkü, çöpün verdiği harareti düşürmek çok zordur. Dikkat edilmesi gereken esas mesele çöpçünün, çocuğun boğazındaki çöpün kaç günlük olduğunu söylemesidir. Eve göndüğünüzde çobanyastığı (eczanelerden almak mümkündür) alıp, çayını demleyin. İçine de şe-ker katıp şekerli yapın ki çocuğunuz içebilsin. Bu çay, çocuğunuzun boğazını mikroplardan temizleyecek ve antibiyotik rolunu oynayacak. Ama çayı çok koyu demlemeyin, çünkü koyu çayın da zararı var. Yok eğer sıralanan 8 elametle çöpçüye gitmişsinizse ve çöp de mideye ötürülüpse (veya çıarılıpsa) onda size birce çobanyastığ 1 kifayet etmeyecek. Bu hâlde çocuğa rastgele hiçbir ilaç vermeyin, doktora danışandan sonra onun tayin ettiği ilaçları içirin. Çünkü çocuk, yeyecekleri çıkardıktan sonra hararetli hâlde çöpçüye götürmüşsünüzse, bu o anlama gelir ki çocuğunuzun boğazı iltihablanıp ve yara olup. Eğer çöp midesine ötürülüpse, sonuçda vücuttan tümüyle dışarı atılana kadar harareti olacak. Her çocuğun boğazında aynı yeyecekten tekrar çöp kalabilir. Bunun için dikkatli olmak lazımdır. Aldığınız oyuncakların tehlikeli olup olmadığından emin olun" (http://qadinlar.biz).

Hem alan araştırmalarından hem de çöpçülük konusunda yazılan kısıtlı bilgilerden (Zeynalova 2013) şu sonuç çıkarılabilir. Büyüklerden farklı olarak çocuğun boğazında çok sayıda krışlar vardır ve yutulamayan bütün nesneler orada takılıp kalır. Boğazda kalan nesneler de ilk önce çocukta halsızlık, zayıflık yaratır. Daha sonra çocuğun harareti kalkır, yürek bulanmaları, kusmalar baş verir, hiçbir şey yeyemez olur. Bunu çöpçüye baş vuran anneler de anlatmaktadırlar: "Men Bakü köylerinden birinde otururam. Küçük, sakin bir ailem, iki evladım var. Kendim de Bakü Devlet Üniversitesini bitirmişem. Aile kurandan sonra ihtisasım üzere çalışamadım. Bunları anlatmakta amacım cahil insan olmadığımı bildirmektir. 2003 yılında aile kurmuşam. 22 yaşında olarken ilk evladım Hayyam dünyaya gelip.

Men şehirde büyümüşem. Çocuk vakti bir azacık hastalanan gibi, anam bizi doktora götürerdi. Ama gelin geldiyim ailenin kayideleri başka idi. Oğlum Hayyam, 3 aylığında ağır hastalandı. Çocuğun harareti inmedi kusmağa ve öksürmeğe başladı. Anam, bacılarım şaşkınlıktan hepsi biribirine karışmışdı. Çocuğu götürmediğimiz doktor kal- 
madı. Doktorlar çocuğun derdine bir ilaç bulamadılar. Artık bebeği hastaneden eve getirdiler.

Günden-güne zayıflayan çocuğa bakıp, her an onu kaybetmek korkusuyla ağliyordum. Bir gün öğlene doğru kaynanam çocuğu çöpçüye götürmeği önerdi. Dedi ki "kızım, gel bir çocuğu çöpçüye de gösterek. Sonra Allah elemesin bir şey olsa, yüreğimizde kalmasın ki neden çöpçüye götürmedik. Razılaşdım, çocuğu götürüp, Maştağa kasabasında oturan çöpçüye gittik. Çöpçü kadın ilk önce çocuğun ellerinden tutup kaldırdı, sonra çok zayıf olduğunu bildirdi. Bu onsuz da bilinen bir şeydi. Men sabırsızlıkla neticeni gözlüyordum. Çöpçü 2-3 defa ağzının içinde ne ise mırıldanarak, oğlumun burnuna üfürdü. Uşağın ağzından sap, elma kabuğu ve kağıt kırıntısı çıktı.

Daha sonra çöpçü, bir kaç gün geçenden sonra yine de gelmeği önerdi. Dedi ki çocuğun kırtlağında kalan bu kırıntılar boğazını yaralayıp. Bir de bakmalıyım. "Bunları söyleyen ana, çocuğun çöpçüden getirildikten sonra sağaldığını bildirdi. Dedi ki çöpçüden geldikten sonra çocuğun harareti indi, kusması dayandı. Men buna: "Çok şaşırmıştım. Sanki möcüze baş vermişti, mene bu iyiliği yaptığı için kaynanama sarılıp öptüm (news.day.az/society/284793.html).

Çöpçüler, şişe kırıntısından, demir, taş parçasından başka, boğazda kalan her şeyi çıkarabilirler. Bunu Ramile Ahmedova da tastikledi: "bir defa şişeni, bir defa da taşı çıkartmamışam. Görmüşem ki ağzından kan gelir çocuğun, deyibler ki ağzında çay bardağını sındırıp. Demişem, şişe kalıp menlik değil. Hiç taşın üfürmeyle kalktığını gören olup mu?! Geriye kalan her şeyi çıkartmak mümkündür, ancak gerek yolunu bilesen ki nefes borusuna salmayasın" (news. day. az/so ciety / 284793.html).

Alan araştırmasında görüşme yaptığımız çöpçülerin büyük çoğunluğu en tehlikeli işin çöpü nefes borusuna salmak olduğunu bildirdiler. Çöpçüler, bunu değişik nedenlere bağladılar. Kendini çöpçü adlandıran, ancak vergi almayanlar üfürürken çöpü, nefes borusuna salabilirler veya boğazda kalan ağır bir nesneni berk üfürmekle, boğazı elle çok sığamakla, boğazda kalan eşyayı çıkartmak için başka bir aletle tepretmekle vs. Bunu, Reyhan Nene de tasdik etti (Gülcahan (Reyhan) Elekberova). Mesela, çöpçü bir bayan hakkında yazılan yazıda doktorlardan bazılarının çöpü çıkarmakta aciz kaldıklarını itiraf ettikleri anlatılır. Çöpçü şöyle der: "Öyle poliklinikler var ki, itiraf edirler. "Semaşko"nun yanında 1 no'lu çocuk hastanesinde defalarca olmuşam. 
8. kilometre çocuk polikliniğinde bir defa serumun altında çocuğun artık ağzı köpüklenip, meni çağırıplar. Gedip çöpü çıkartmışam, çocuk kendine gelip, serumu açıplar, çocuk da kalkıp ayağa. Öylesi olur ki çocuğun boğazını gurcalayır, çöp de gedip düşür nefes borusuna. $\mathrm{O}$ hâlde men de tedavi etmirem, çünkü ona ilaç etmek olmur. Berk bir şey nefes borusuna düşdü, oradan zor çıkar. Çıkardınca da çocuk ölebiler" (news.day.az/society/284793.html).

Burada bir çok spekulasyonlara neden olan çöpçülerin tedavi karşılığı aldıkları para meselesine de değinmek derekir. Çöpçülerin tedavi karşılı̆g aldıkları ücret o kadar da çok değildir. Özellile kırsla kesimde çalışan çöpçüler 5-10 manata hizmet gösteriyorlar. Şunu da demek lazımdır ki, Bakü'de görüşme yaptığımız çöpçülerin çoğunluğu dediklerine ve çöpçüye giden ebeveynlerin verdikleri bilgiye göre tedavi karşılığının 15-20 manat olduğu tespit edildi. Bu da paranın devalvasyonu, her gün pahalanan gıda ve diğer telabat mallarına göredir.

\section{Çöpçülerin Diğer Hastalıkları İyileştirmesi}

Azerbaycan'ın değişik bölgelerinde apardığımız alan araştırmasından edinilen bilgiye göre çöpçülerden bir çoğunun sadece çöp çıkarmadığını, aynı zamanda diğer rahatsızlıkları, hastalıkları da tedavi ettiklerinin şahidi olduk. Bu yetenekli halk hekimlerinin çöpçü-lükle beraber bir kaç hastalığ1 tedavi edenlerine Kuzey-Batı bölgesinde hanıkçı, Bakü ve Güney bölgesinde ise henekçi denilir. ${ }^{2}$ Genelde bu halk hekimleri hem çöpçü hem sınıkçı/çıkıkçı hem hacamatçı hem bel çeken hem de göbekdüşmeni iyileştiricidirler. Bütün henekçiler/hanık çıların çöpçülük yaptığını söylemek de doğru değildir, ancak bütün

2. Hanıkçı/henekçi terimi daha geniş alanda kullanılmaktadır. Nitekim teneffüs organlarının (burun, boğaz, nefes borusu, göks) bozulması sonucunda öksürekli hastalıklar yaranır ki bunun da başlıca sebebi soyuk algılamasıdır. Buna Azerbaycan'ın bir çok bölgesinde "hanık olmak" denilir. "Bu tür hastalıklar aynı zamanda zature, tumov, göyöksürek, inak vs. adlarla da bilinir. Teneffüs organlarının hastalıkları genel olarak soyuk algılamasından ve bunun sonucunda oluşan viruslardan türeyir. Türkeçareliğin bir sahası olan olan hanıkçılık/henekçilikta zature, zökem, tumov ve göyöksüreği olanları tedavi etmek için kekotu, nane, yarpız, kuşburnu, sarıçiçek, evelik, lavanda vs. demlenmiş çaylar önerilir, balın sıcak suda hazırlanmış şerbetinin, zirinc şerbetinin, pişirilmiş 1lık sığır südünün, şalğam şerbetinin, üzüm sirkesinin yararlı sağaltma vasıtası olduğu gösterilir" (Azerbaycan etnografiyası 2007: 298). Azerbaycan'da boğaz bademciklerinin şişip irinlemesine ınak, henak, hanık, henik denilir ki henekçi de aslında boğazı silen, sıvayan anlamına gelir. Onlardan bir çoğunun çöpçülük yapması da bu yüzdendir. 
çöpçüler hemen hemen henekçidirler. Nitekim henekçi daha çok boğaz iltihaplanmasını tedavi konusunda uzmanlaşmışırır ve bu tedavini de otlarla, çaylarla hem de ovsunla yapar. Ancak çöpçülük yapan hanıkçılara geldikte şunu söylemek gerekir ki, Kazak bölgesinde yaşlı bir hanıkçının çöpçülük, sınıkçılık/çıkıkçılık ve göbekçekmelik yaptığının şahidi olduk. Onun anlattığına göre evlatlarından yalnız kızı çöpçülük yapmaktadır.

Masallı ilçesinde henekçi denilen ve bir kaç hastalığı tedavi edenler, esas meslekleri olan çöpçülükle beraber boğaz iltihaplanmasını da sağaltır, bel çekmekle evlatsızlı̆̆a çare bulur, veremi, zatureni iyileştirirler. Daha da geniş sahaya nüfuz eden çöpçüler de vardır. Mesela, çöpçülükle beraber sınıkçılı̆̆ı, göbek düşmesini, damar kaçmasını, boyun tutmasını, boğaz ağrılarını tedavi edenler de vardır. Bundan başka omurga ağrılarını, bel tutmalarını, yel hastalıklarını vs. iyileştiren henekçilere de rastlamak mümkündür. Hatta bir grup halk hekimleri çöpçülükle beraber göbek düşmeni, karın ağrılarını, boğaz ağrılarını, diş ağrılarını tedavi edir, hacamatla kan alır, hamile kalmak için karın bağlayırlar vs. Mesela, Masallı şehrinde oturan ve Reyhan Nene adıyla bilinen seksen beş yaşlı tanınmış çöpçü Gülcahan Elekberova diğer hastalıkları iyileştirdiğini şöyle anlattı: "Men mide de s1ğıyıram. Bakü'den gelirler mide sığıyıram. Özür dilerim çocuğu olmayan kadının karnını çekip bağlayıram, olur çocuğu. Bir defasında meni İrana götürdüler, Erdebile, on beş yıldı evlenmiş bir gelin getirdiler, kocası boşamak istiyor onu, kayın validesi izin vermir boşamağa, bular menim yerimi bildiler. Getdim Erdebil'e. Üç gün aç karnına çekdim, bağladım. Duydum ki, doğurup, kızı olup. Men çocuk tutup ebelik etmirem, ancak bel bağlıyıram. Amma esas işim çöpçülüktür" (Gülcahan (Reyhan) Elekberova).

Tanıklar da çöpçülerin bir kaç hastalığı iyileştirdiklerini onayladılar: "Sonra yüz yaşlı kadın vardı, hem çöpçü idi hem boğaz gelirdi ha, angina gibi, onu sığayırdı, ağrıları götürürdü. Meysare adında bir kadın vardı, bak o dediğim işleri yapırdı" (Tahir Hüseynov).

Çöpçülerin büyük çoğunluğu bir kaç türkeçareliği, mesela kadın hastalıklarını sağaltmağı, bel çekmeni, göbek götürmeni, hacamatla kan almanı vs. yapırlar. Bu da onların doğrudan da vergili insanlar olduğunu kanıtlıyor. Ancak onların asıl uzmanlık alanı çöpçülüktür.

Sonda bir meseleye tokunmağın vacip olduğunu demek lazımdır. Çağdaş dünyamızda modern tıbbın yok etmeğe çalıştığı geleneksel 
halk hekimleri, aynı zamanda çöpçüler de bir kaç sebepten dolayı kendilerini az da olsa komuflaj etmek zorundadırlar. Nitekim alan araştırması zamanı görüşme yaptığımız çöpçüler sadece uygulama tedavilerinin kameraya alınmasına değil, hatta fotolarının çekilmesine de kesinlikle itiraz ettiler. Hatta onların hakkında yazmamalarını israrla rica ettiler. Mesela, Reyhan Neneyle Rayse Dadaşova sorulara kaçamak cevap verdikleri gibi tedavinin çekilmesine, fotolarının yapılmasına da izin vermediier. Bunu polislerin onları rahatsı edecekleri, para isteyecekleri ile izah ettiler. Bakü'nün Ahmedli köyünde yaşayan Ramile Ahmedova: "Bir defa "Hazar" televiziyonunda seyahet programı yapan gözlüklü genç var e, bak onun çocuğunun çöpünü çıkarttım. Dedi ki Ramile teze, gel senden veriliş çekim, razı olmadım. Sonra polisler rahatlık vermeyecek. Şimdi siz de yazacaksınız, gelecekler ki internette senden yazıplar, bizim de payımızı ver”, demekle meseleye açıklık getirdi (news.day.az/society/284793.html).

\section{Çöpçülük Öğrenilmez, Verilir}

Vergi, İslamiyet'ten önceki kültürümüzde Tanrı'nın veya ruhların seçilmiş insanı göreve çağırmak şeklidirse, Türk İslam medeniyetinde Allah'ın (cc) kuluna lütfudur. Halk hekimliği, bütünlükte bir vergi meselesidirse çöpçülük de bunun en belirgin olanıdır ve şaman kültürünün İslami varyantıdır. Tedavi eden kadın şamanlar, sağaltan çöpçülerle aynı kültür mirasını paylaşmaktadırlar. Çöpçülük halk inancına göre, tıpkı şamanlık gibi öğrenilmez, soyla geçer veya uykuda verilir. Gerçek çöpçüler, soyunda bu mesleği bilenlerdir ve onlara da çöpçülük anaları, nineleri veya ulu ecdadları tarafından verilmiştir. O bakımdan çöpçülük kalıtsaldır, vergi şeklinde göreve çağrılmadır:

"Seksen beş yaşım var. Yetmiş yıldan çoktur ki çöpçülük yap1yorum. Men seyidim, ağır seyidin kızıyım. O vakit bu çöpçülüyü mene uykuda verdiler, nine canı. He, çöpçülük öğrenmekle olmaz, gerek vergili olasan, vergi verile. On iki yaşımdayken mene verilip bu çöpçülük. O zamandan da çöpçülük yapıyorum. Oğlum mene deyirdi ki çöpçülük yapma. Bizi rüsvay etme. Bunun için mene çok azap verdi.

Çöpü burunnan pülüyürem, boğazdan gelip düşür. Çöpü içeri ötürmek iyi bir şey değildir. Çöp, büyüklerde de kalanda çıkartırım. Büyükler de gelir, boğazlarında balık kemiği kalır, çıkartıram. Çoklarının çöpünü çıkartmıram. Çöpü dışarı çıkartıram. İçeri ötürsem mideye-zada batabiler" (Gülcahan (Reyhan) Elekberova). Büyüklerin çöpü- 
nü Çöpçü Resmiye de burundan üfürmekle çıkartdığını bildirdi. (Çöpçü Resmiye).

Vergi alan çöpçüler için aslında zor olan hiçbir şey yoktur. Çöpçülük hem kalıtsaldır hem soyunda çöpçü olmayana uykuda verilir hem de seyid evlatlarına verilir. Bunlardan en çok rağbet göreni vergi ile ötürülen kalıtsal çöpçülüktür.

Çöpçü Nargile bildirir ki çöpçünün yaptıklarını hiçbir doktor yapamaz. "Bu halk hekimliğinin kendine özgü sırları var. Bu, bir ilahi vergidir. Men bunun sırlarını açamam. Ama ortada gerçekler olmasaydı, bu kadar çocuk sağalmazdı. Uzun yıllardır, çöpçülük yapıyorum. Bu yıllar arzında bir defa da olmayıp ki çocuk sağalmasın. Elimi çocuğun boğazına dokunduran gibi bilirim ki çöpü var, yoksa yok" (news. day. az/society/284793.html).

Masallı bölgesinin Boradigah kasabasında çöpçülük mesleğiyle uğraşan orta yaşlarında bir bayan, soyunda çöpçü olmamasına, seyid kızı olmamasına bakmaksızın çöpçülüyün ona rüyada verildiğini anlattı. "Kardeş, bu mesleği mene rüyada bir çocuğun çöpünü çıkarmağı önerenler verdi. Önce men inanmadım. Hemen gece çok ağladım, çok ağladım, cüma akşamıydı. Çok ağladım, evde küçük çocuklar, yokluk, geçimsizlik, fakirlik.

Gece yattım, rüya gördüm, mene bir çocuk verdiler, sen bunu püle, püle (üfle) dediler.

Dedim:

- Men çopçü değilim.

Dediler:

- Sen bu çocuğu püle.

Men bu çocuğu püledim.

Sabah oldu kardeş, dedim böyle-böyle, bir rüya gördüm, bald1zım da evdeydi, kaynanam da baldızım da güldüler. Bak beş kızım var, dört oğlum var, dört de gelinim var. Eğer bu vergi olmasaydı men bunu öğreterdim kızlarıma, yahud vererdim gelinlerime oturup kendilerine ekmek kazanardılar. O çöpçüleri men dinliyorum, menim hoşum gelmir. Deyir ki men çöpçülüğü, bu mesleği öğrenirem, ne bilim, der ki men çöpçülük yapıyorum, menim onnan hoşum gelmir. Bunu öğretmek lazım değil, bu öğretilen meslek değil, o yalandı. Onu kim söylüyorsa o yalandı" (Rayse Dadaşova).

Çöpçülüğün soyla geçtiğini başka çöpçüler de bildirdiler. Mesela Milli.az.saytında aslen Tovuz ilçesinden olub Bakü'nün Ahmedli köyü- 
ne gelin gelmiş, şimdi 46 yaşlarında olan Ramile Ahmedova da çöpçülüğün bir vergi olduğunu ve soyla geçtiğini tasdikledi: Baba ninemde olub. Kaynanam da baba ninemin kardeşinin eşidir. Men bu aileye gelin gelende ç̧̋pçülük mesleğini ona göre yapmadım ki kaynanamın önüne geçmeyim. Sonra kaynanam dedi ki kızım, bu iş senin soyundan gelir, men de o ocağa düşüp öğrenmişem, senin görevindir, sen uğraş (news. day.az/society/284793.html).

Bakü'de Hutor adlanan yerde oturan ve görüşme yaptığımız çöpçü Resmiye anasının çöpçülük yaptığını, kendisinin de ondan el aldığını söyledi. (Çöpçü Resmiye)

Türk kültüründe şamanların ecdad ruhları tarafindan göreve çağrılması rüyada gerçekleştĭgi gibi (Bayat 2005; Bayat 2006) çöpçüler de vergini uykuda alır ve bu görevi yerine getirmedikleri zaman da rahatsız edilirler. Mesela bir çöpçü vergi ile alakalı şöyle bir açıklama yaptı: "22 yıldır bu işle uğraşıram. Şimdiye kadar hiçbir ebeveyn menden narazı kalmayıp. Bura gelin gelende çöpçülüyü bilirdim, ancak utanırdım bildirmirdim. Sonra havalandım, başım musibetler çekti. Mene dediler ki iki sebepten bu duruma gelmisin; birincisi, sen Tanrı tarafından verilmiş verginin taşıyıcısısan, neden borcunu yerine getirmirsen. İkincisi, kendi elinle içki şişesini götürmüsün. Evde eşim, iki oğlum var. Men onlara hüküm edemem ki içki içmeyin, ancak vergili ocağa içki olmaz, günahtır. Sonra yavaş-yavaş kendi çocukarımın çöpünü çıkarttım, duyan, bilen geldi, hepsine yardım ettim. Şimdi yüzlerle insanlar gelir, çocuk kaytarır, harareti var, bakıram görürem ki çöpü var, nasıl çıkartmayım. Tanrı, bu işi mene hevale edip, ne kareyem ki” (news. day.az/society/284793.html).

Çöpçülere göre, çöple beraber ağızdan kötü enerji de çıkır. Ona göre de yakında durmak, bir kaç seansı izlemek insanda hastalığa sebep olabilir. Buna kötü kara enerjinin getirdiği ağırlık denilir. Tek kelimeyle çöpçülük, majik söze, majik güce inamın ürünüdür ve inanç dünyamızla birebir bağlantılıdır. Bu da şamanlıkta her bir hastalığın kaynağının kötü ruhlar olduğu bilgisiyle örtüşür.

Vergiyle bağlı bir mesele de çocuğun boğazında bir daha çöp kalmaması için “çöpü bağlamak”tır. Bazı çöpçüler bildirdiler ki çocukta bir daha çöp kalmaması için boğazda kalan çöpü çıkarttıktan sonra onu "sındırmak" lazımdır. "Bu, çöpü bağlamak adlanır, bağlayırık ki bir daha çöpü kalmasın. Bunun için de para ödemelisin". Çöpü bağlamağın bir usulu da çocuğun boğazından çıkan ilk çöpün her han- 
gi bir eşyaya bağlanarak çocuğun üzerinden asmak veya saklanmak yoluyla gerçekleşmesidir. "Böyle oldukta, çocuğun bir daha çöpü kalmaz". Çöpü bağlamağın bir yolu da çocuğun ağzından çıkan ilk çöpünü bir şeye sararak onun üzerine dikmekdir. O hâlde çocukta, bir daha çöp kalmaz. Ancak kaynak kişi, çöpçülerin ilk çıkan çöpü çoğu zaman ebeveynlere vermediğini de bildirdi (news. day. az/ society /284 793. html' Bazı çöpçüler çocuğun boğazında bir daha çöp kalmaması için zemanet de verirler.

Bakü'nün Surahanı köyünde oturan ve çöpçülük yapan yaşlı bir bayan çöpü bağlamak için kırk anahtardan ve bakır tastan yararlandı. Tasın içindeki suya ovsun okuyarak çocuğun yüzüne serpti. "Çok olsun ki bir defa çöp kalar, ancak bir daha kalmaz”, dedi. (Çöpçü Fatma)

"Çöpü bağlamak" adıyla bilinen uygulamaya münasebet birmanalı değildir. Hatta bazı çöpçüler çöpü bağlamağın hiçbir faydasının olmadığını bildirdiler. Çöpü bağladım deyenlerin başarılı olmadığını tanıklar da kanıtladılar. Nitekim hem deneyimli çöpçülerin hem de ebeveynlerin anlattıklarına göre çöpü bağlamak her zaman kendini doğrultmur. Çöpü bağlamak çoğu zaman çocuğu korkutmakla yerine getirilir. Korkutulan çocuk da yemek yerken eline geçen her şeyi ağz1na koymur. Deneyimli çöpçülerin görüşlerine göre, boğazda oluşan boşluk zamanla daralır ve belli bir yaştan sonra çocuğun boğazında çöp kalmır (http://qadinlar.biz).

Çöpü bağlamak da aslında vergi meselesi, çöpçülüğün bir sihir mesleği olduğunu kanıtlamaktadır. "Çöpü bağlamak" adıyla bilinen bu sihri yöntem değişik yollarla gerçekleşir. Mesela, çöpçülerden bazılarının dediklerine göre, çöpü bağlamak kendini doğrultmayıp, ben hatta kendi çocuğumu guya bağlamışam, ama yine de çöpü kalıp. Çocuğun vücudu güclenene kadar boğazında çöpü kalacaktır. O vakit ki çocuk kendi yutkunup yemeği iyice yutabilecek, işte o zaman çöp kalmayacak (news.day.az/society/284793.html). Tek kelimeyle, çöpçülükte şamanlıktan ve eski halk hekimliğinden kalma bir çok majik söz ve ritüeller vardır ki bu gün anlamını değişse de, türkeçare ortamında yaşamağa ve yaşatılmağa devam edir.

\section{Sonuç}

Modern tıbbın savaş açttğı geleneksel tedavi yöntemi olan çöpçülük her geçen gün halk arasında rağbet görmekte, çöpçülere baş vuranların sayı artmakta ve sosyal terkibi de deyişmektedir. Çöpçülük, köy hayatından çıkarak, polikliniklerin, hastanelerin, doktorların çok 
olduğu büyük şehirlere yüz tutmuştur. Bunun bir sebebi Azerbaycan' da tıbbi hizmetin paralı ve paha olması, diğer sebebi de çöp konusunda doktorların yetersiz kalmalarıdır. O nedenle çöpçülerin yardımına gereksinim duyanların içinde sadece okumuş insanlar değil, değişik uzmanlık alanından olan doktorlar da vardır. Çöpçüler, çocukların boğazında ilişip kalan ve çöp adlandırılan gıda kalıntılarını, çocuğun ağzına aldığı diğer eşyaları çıkarmakla uzmanlaşıp kalmamış, aynı zamanda diğer hastalıkları - boğaz ağrılarını ve iltihabını, bel çekmeği, göbek düşmesini götürmeği, hacamatla kan almağı vs. de tedavi eder duruma gelmişler. İşlevine ve toplumsal konumuna göre, onlara duyulan saygının esas sebebi tıpkı şamanlar gibi, vergili olmalarıdır. Çöpçülük de şamanlık gibi kalıtsaldır, öğrenilmez verilir; bu ise halen de Türk milletinin vergili insanlara olan inamından kaynaklanır.

Bugüne kadar yeterince araştırılmamış halk hekimliyinden biri olan çöpçülük, her ne kadar Azerbaycan sahası için özgü olsa da, buna benzer uygulamaların diğer Türk topluluklarında da gerçekleştirildiği bilinmektedir. Çöpçülük geleneksel tebabetin belki de en canlı ve halen de yaşamakta olan sahalarından biridir. Ancak türkeçareliğin bu növü ciddi şekilde, kuramsal bir çerçevede araştırılmadığından onun şamanlıkla, eski tebabetle, kadın otaçılarla alakasının hangi düzeyde ve düzlemde olduğu bilinmemektedir. Türk kültür paradigmasının türkeçarelik adıyla bilinen geleneksel tedavi, iyileştirme gibi çeşitli alanlarından biri olan çöpçülük, sözün sihri ve pratik yetenekle birleşerek kendine özgü halk hekimliği mesleğine çevrilmiştir.

KAYNAKÇA

Alekberli F. (2001); Tısyaça i odin sekret Vostoka. Baku: İzdatelskopoligra fiçeskiy tsentr " $\mathrm{T}$ "

Alekberli F. (2005); "Meditsina v drevnem i srednevekovom Azerbaydjane", Azərbaycanda tibb elminin tarihi problemleri. I Respublika Elmi Konfransının Materiallar1. Bak1, 1-2 fevral 2005, s.168-169

Azerbaycan etnografiyası (2007); III cild. Bakü: Şərq-Qərb

Bayat F. (2004); Türk Şaman Metinleri. Efsaneler ve Memoratlar, Ankara: Piramit

Bayat F. (2006); Ana Hatlarıyla Türk Şamanlığı, İstanbul: Ötüken Yayınları.

Eyvazkızı R. Çöpçüler, yoksa asan yolla pul kazananlar?! "Azadqadın.az"

Qadın İnformasiya Portalı. 20 dekabr 2012 (http://azadqadin.az/aktual/myd/1086-

199214 p1992201399 ryoxsaasanyollapulqazananlar.html)

http://qadinlar.biz

Kaynak kişi: Sümeyra Sinoğlu, 1991 doğumlu, Sandıktaş Köyü, Derepazarı/ Rize, 2016 yılında derlendi 
Kaynak kişi: Gülcahan (Reyhan) Elekberova, 1928, okuma-yazma yok, Masallı şehri, 2014 yılında derlendi

Kaynak kişi: Raysə Dadaşova, lise mezunu, Boradigah/Masallı, 2014 y1lında derlendi

Kaynak kişi: Tahir Hüseynov, 1953, öğretmen, Hil köyü/Masallı ilçesi, 2014 yılinda derlendi

Kaynak kişi: Çöpçü Resmiye, 45 yaşlarında, lise mezunu Hutor 1. sıra, ev 5/ Bakü, 2016 yılında derlendi

Kaynak kişi: Çöpçü Fatma, 60-65 yaşlarında, lise mezunu, Surahanı/Bakü, 1999 y1lında derlendi

news.day.az/society/284793.html

Zeynalova V., Mustafayeva S. "Halk tebabeti usulu ile...", Region plus gazeti, 30 aprel 2013-cü il 